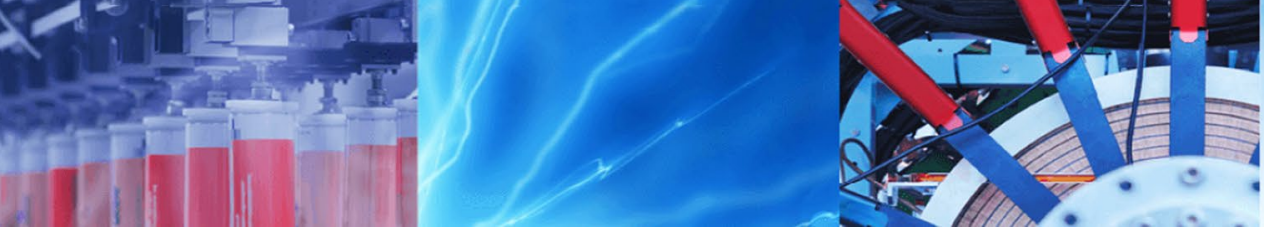

Research Article

\title{
Comprehensive study of the wet and dry spells and their extremes in the Mediterranean climate basin Northern Tunisia
}

\author{
Majid Mathlouthi ${ }^{1} \cdot$ Fethi Lebdi ${ }^{2}$
}

Received: 22 June 2021 / Accepted: 14 October 2021

Published online: 02 November 2021

(c) The Author(s) 2021 OPEN

\begin{abstract}
Abstract In agriculture, the characterization of dry spells is essential whether it is to calibrate the water needs of crops or the flow rates of rivers. This study seeks to develop a discretization of dry and wet spells on a monthly scale while evaluating the risk of extremes using the renewal wet-dry spell model. This model consists of defining the wet spell according a negligible precipitation threshold. The structure of the model is that all parameters of the climate cycle, including its length, are random variables. To study the trend of the parameters we use the Mann-Kendall test, while the magnitude is evaluated by the Sen's estimation method. The approach is applied to Ichkeul Lake basin in northern Tunisia to demonstrate its capacity. This region is of great agricultural and water importance, although it holds six large dams. The results show that the duration of the dry and wet spells reach's, respectively, 49 days and 17 days. The maximum dry spell was 49 days in 1982. The Mann-Kendall test revealed three stations with significant positive trend of the monthly extreme dry spell length (at March) located in south and east of the basin. The trend analysis of the seasonal rainfall number showed one station with significant negative trend in east and one station with significant negative trend in the center of the basin. Results indicated that no significant changes in the start and end of rainy season have occurred over the past years. But a great relation with a subsequent length exists. The results of this research assist farmers and managers in establishing drought management plans. It allow, among other things, to calibrate simulation models for a more realistic management of water reservoirs. It also makes it possible to plan irrigations on a more different basis from that of observations made at regular time intervals.
\end{abstract}

\section{Highlights}

- We analyze the trends of the drought in Ichkeul lake basin, Northern Tunisia, characterized from the daily rainfall data of five stations. The alternating wet-dry spell model and a precipitation threshold value are used to define the rainfall/dry event. The Mann-Kendall test and the Sen's estimation method were used to analyze the possible trends and the magnitude of variables analyzed, respectively.
- The results show an increasing trend of maximum monthly dry spells. No significant changes in the start and end of rainy season have occurred over the past years.

- These analyses provide useful information for science and society and make it possible to minimize unexpected damage due to long dry spells and to have effective and efficient planning for various stakeholders.

$\triangle$ Majid Mathlouthi, majid_mathlouthi@yahoo.fr; Fethi Lebdi, Lebdi.fethi@yahoo.fr | ${ }^{1}$ Research Laboratory in Sciences and Technology of Water at INAT, 43 Avenue Charles Nicolle, 1082 Tunis, Tunisia. ${ }^{2}$ National Agronomic Institute of Tunisia (INAT), University of Carthage, 43 Avenue Charles Nicolle, 1082 Tunis, Tunisia. 
Keywords Wet and dry spell - Water release schedule . Crop growth - Rainfall threshold

\section{Introduction}

It is well known that short or prolonged drought events, intense floods are often associated with adverse impacts either on society or the environment [1]. In the scientific literature search, there are several definitions for drought. A dry event can be defined as a series of consecutive dry days with no precipitation or less than a certain threshold value. This threshold can be defined according to physical considerations or by performing a statistical rainfall analysis [2]. The planning, development and management of water resources are affected by climate change, so today the issue of minimizing the adverse effects of drought has become very important [3]. Reiser and Kutiel [4] have studied the annual rainfall regime in the Valencia and Larnaca stations of the Mediterranean basin. They looked at several parameters, such as: total precipitation, date of accumulated percentage, length of rainy season, number of rainfall spells, rainfall spell yield, ratio between average and median rainfall, the relationship between accumulated precipitation and the number of rainfall spells and the dry spells distribution. They concluded that precipitation is totally absent during the summer in Larnaca, which better meets the definition of a Mediterranean climate than that of Vamancia. Caloiero and Coscarelli [5] studied the mean and maximum lengths of dry/wet spells, the number of dry and wet spells with different lengths, and the contribution of dry/wet spells with different lengths to the total number of dry/wet days in the Calabria region (southern Italy), over a period of 56 years (1951-2006), considering both yearly and seasonal scales. The results showed a similar behavior of dry and wet spells in the spatial distribution of mean lengths, and may be useful for water resource management (concerning dry spells) and risk reduction (regarding the wet spells). Raymond et al. [6] investigated the evolution of the long dry spells in the Mediterranean Basin during the rainy season and for regional future climate projections of the Mediterranean and European Coordinated Downscaling Experiment initiatives. The main results are an increase in the number of very long dry spells and an increase of their mean duration and spatial extent. Rivoire et al. [7] compared the extreme dry spells, defined either with a fixed threshold for a dry day $(1 \mathrm{~mm})$, or with a time-varying threshold estimated from reference evapotranspiration (ET0), of the basin Mediterranean. Results indicated positive trends in ETO during the summer months in particular. A seasonal behavior has also been observed: in winter, the distribution of extreme dry spells is similar if it considers a fixed threshold $(1 \mathrm{~mm})$ or a time-varying threshold defined with ETO. However, during the summer, the extreme dry spell durations estimated with a threshold of $1 \mathrm{~mm}$ are greatly underestimated compared to extreme dry spells calculated with ETO.

By analyzing the decadal to centennial scale hydrological response of southeastern Spain drylands, Machado et al. [8] pointed out that the recurrence of dry phases has been higher since the beginning of the seventeenth century, compared to the frequency of continuous wet phases with marked annual variability. They also concluded that the trend for longer dry spells and increased interannual variability and irregular seasonal distribution of precipitation is considered essential in the modeling for this specific arid Mediterranean region. Interest marked by Salvati et al. [9] is to develop a simple drought severity index (DSI), obtained from only two input variables (rainfall and reference evapotranspiration), able to produce information on a detailed geographic and time scale. Using dry spell climatology they estimated duration, intensity and severity of drought on a daily basis over the test period 1988-2003 in Italy. They concluded that the most arid period in Italy was recorded during spring-summer 2003, when especially dry conditions occurred in northern and central Italy. DSI correctly indicates a significant increase of drought from March to July 2003 throughout Italy. It may be used to assess the agro-climatic conditions occurring in a certain location through only two input variables. It allows a synthetic description of drought episodes in terms of both dry spell length and water balance.

The study by Ben Mhenni et al. [10] investigated the characteristics of drought and its effect on vegetation and agricultural productivity in three areas of Tunisia between 1982 and 2011, by exploiting meteorological drought indices and soil moisture and identifying the most appropriate index for each area.

The results showed that the meteorological droughts were short and frequent, triggering soil moisture droughts that were long lasting and intense. The standardized precipitation index was identified as the best indicator of agricultural vegetation and droughts in the northern forest, while the Palmer drought severity index was the best in the central steppe and southern desert. The lagcorrelation analysis found that the response of greenery, vegetation and wheat productivity to droughts was more pronounced and had a significantly longer lag in the central steppe than in other regions.

The review of Loon [11] provides an overview of the current state of scientific knowledge on the characterization of hydrological drought. It attaches particular attention to the influence of climatic and terrestrial properties on the hydrological characteristics of drought. In addition, it 
highlights that the current use and usefulness of different drought indicators is highlighted and it discusses recent advances in drought monitoring and forecasting. It provides a summary of the research on hydrological drought projections for the future. In a succinct way, the link of the hydrological characteristics of the drought with the impacts and the problems related to its management was also dealt with. Finally, the author defined the challenges for future research on hydrological drought that concern international initiatives.

During rainy seasons, success and failure in crop production dependent on frequency and length of dry spells $[12,13]$. Water deficit resulting from drought reduces crop yield because of its negative impacts on plant growth [13]. Changes in the magnitude and frequency of droughts due to climate change will have severe impacts on agriculture, especially crop production, cropping systems, and livestock [13]. Crop water needs differ according to species and climatic parameters [14]. It should be noted that the additional irrigation of crops during the rainy season depends on the distribution of the precipitation during the season and therefore the distribution and the occurrence of dry spells. The scientific literature is very rich with regard to the modeling, analysis and investigation of the drought phenomenon..

This study has three main objectives: (1) Identify and analyze the trend of events (dry/wet) under prior knowledge of the characteristics of dry/wet spells and demarcation of start and end of rainy season in northern Tunisia with Mediterranean climate; (2) Test analysis of the observed variability of regional drought occurrence at the catchment scale (3) Contribute for the depreciation of the minimization of damage due to long dry spells and to have effective and efficient planning for various stakeholders of this region.

\section{Case study}

Tunisia is one of the Mediterranean countries least endowed with water resources. Water resources in Tunisia are characterized by scarcity and a pronounced irregularity. As a result, water has become in Tunisia in recent decades, a decisive factor in spatial planning and economic and social development [15]. The most recent assessment of water resources is 4503 million $\mathrm{m}^{3}$ of annual resources, of which 2700 million $\mathrm{m}^{3}$ is surface water [16]. In order to respond to a growing demand, strategies and master plans for mobilization and use have been drawn by the water services of Tunisia. The main surface water mobilization works (large dams, collinear dams and collinear lakes) were built on the rivers of the basins located in the Extreme North of the country, which provides $81 \%$ of the surface water resources (Table 1). These basins are characterized by young reliefs, in geological terms, presenting valleys and steep ridges, dominated, on the one hand, by marl soils and soils vulnerable to erosion and, on the other hand, by a forest cover limited to the most watered parts and a seasonal vegetation cover.

Ichkeul lake basin is one among the tributaries of the Extreme North basins. The total length of the main River (wadi Sejenane) is about $60 \mathrm{~km}$ and its area is $2120 \mathrm{sq} \mathrm{km}$. It bounded by Latitude 4,066,689 $\mathrm{m}$ to 4,108,664 $\mathrm{m} \mathrm{N}$ and Longitude $510,000 \mathrm{~m}$ to $570,500 \mathrm{~m} \mathrm{E}$ (Fig. 1). Five large dams location serving approximately 7000 ha of irrigated perimeters of fruit trees, vegetable crops, fodder and cereals is reported also in this map. These dams contribute also to water transfer from North to Center and Sahel of the Country, the floods protection of Mateur city and the hand of the ecological balance of Ichkeul Lake.

Ichkeul lake basin is more often under the Mediterranean influence, sub-humid and has mild winters [17]. According rainfall data of stations operated by General Directorate of Water Resources (Tunisian Ministry of Agriculture), on average the rainiest months for autumn season are November $(96.9 \mathrm{~mm})$; December $(105.5 \mathrm{~mm})$ for winter season; March (61.3 $\mathrm{mm}$ ) for spring season, and June $(12.1 \mathrm{~mm})$ for summer season. The driest month is July (3.3 mm) (see Fig. 2). On a monthly scale, apart from the dry season, the highest average precipitation is recorded in December (105.5 mm) then in January $(96.9 \mathrm{~mm})$. On the other hand, the lowest precipitations are observed in May and September with, respectively, $27.1 \mathrm{~mm}$ and $44.2 \mathrm{~mm}$. But the rains are much more complex. They appear quite suddenly in September, quickly reaching a maximum in October. From November to February a glut of winter, this can last until March exist. From May the precipitation descend rapidly, and preceded the summer shortage that will last until August (Fig. 2). About $43.6 \%$ precipitation occurs during December to February, 31.8\% during September to November and $21 \%$ during March to May (Table 2). The seasonal distribution of precipitation shows a relative predominance of winter season, but autumn and spring are also relatively rainy (Table 2 ). Most of this basin

Table 1 Regional distribution of the Tunisian surface water resources $\left(10^{6} \mathrm{~m}^{3}\right)$ in 1995 [16]

\begin{tabular}{|c|c|c|c|c|c|c|c|c|c|c|}
\hline Region & North west & Northeast & Total north & Midwest & East center & Total center & South west & South east & Total south & Total \\
\hline Resources & 1585 & 605 & 2190 & 190 & 180 & 370 & 20 & 120 & 140 & 2700 \\
\hline
\end{tabular}




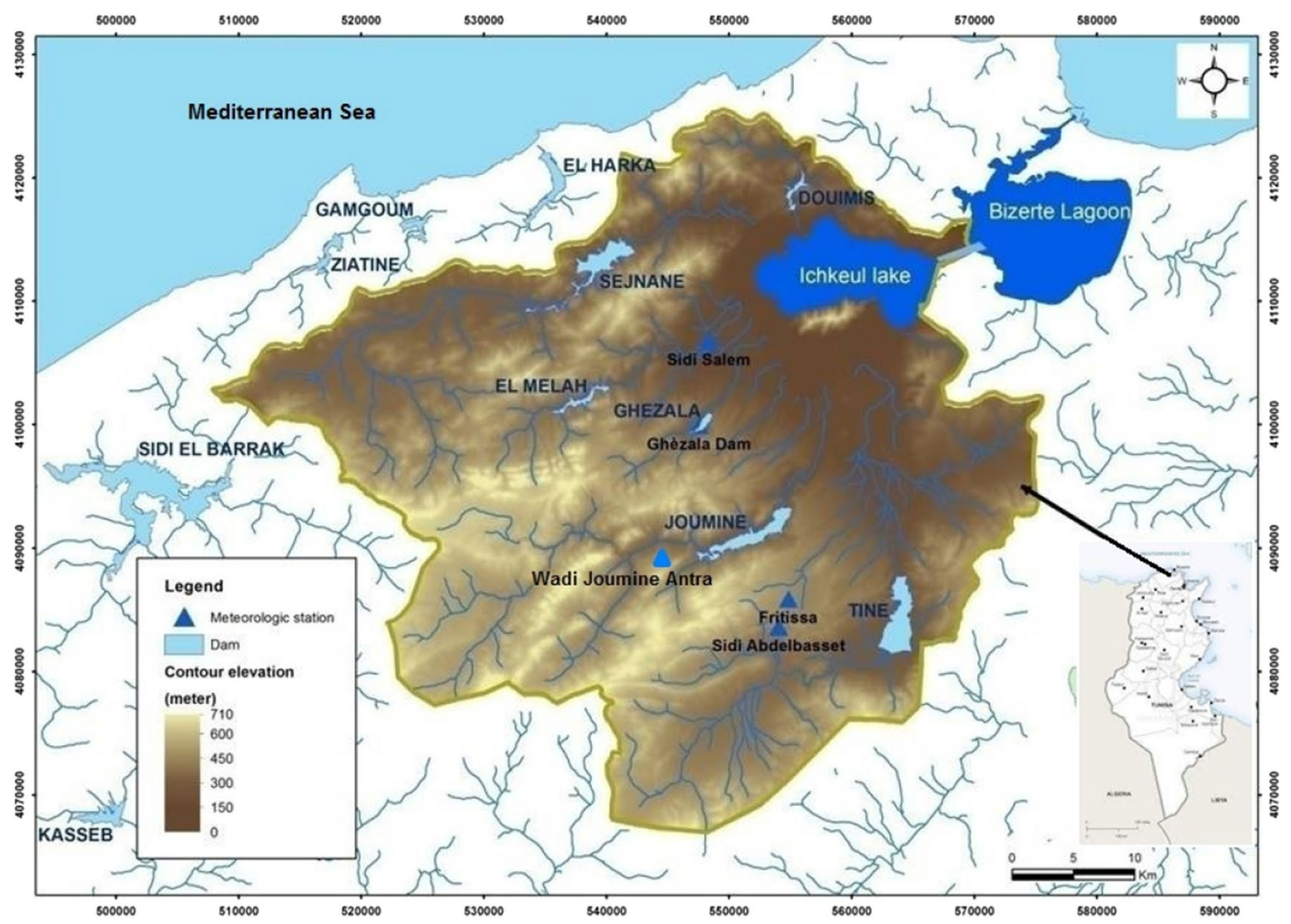

Fig. 1 Location of the Ichkeul lake basin. The studied rain gauges stations are shown on this map

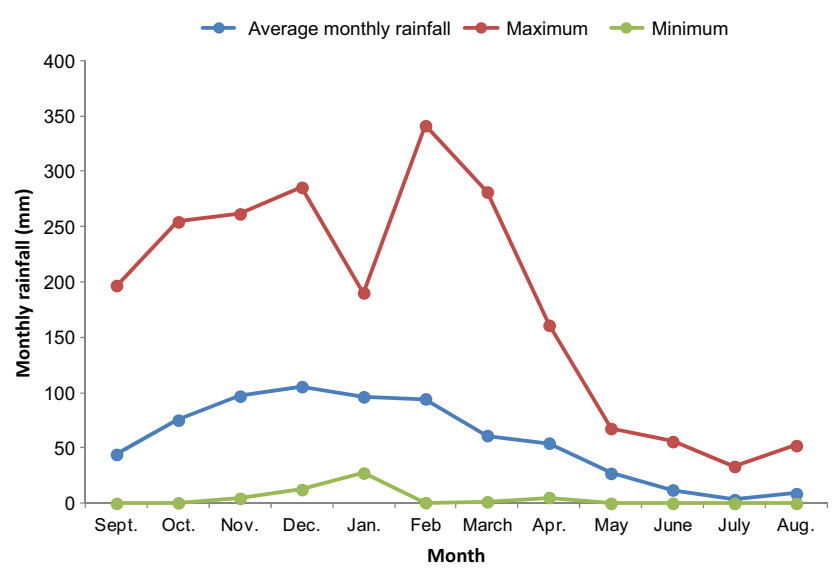

Fig. 2 Evolution of the monthly rainfall at Ghèzala Dam station (1968-2009)

area receives precipitation less than $550 \mathrm{~mm}$. According to daily observations performed at Ghèzala Dam site, the highest annual precipitation, $1104.30 .8 \mathrm{~mm}$, was recorded during 1995 and the lowest 408.6 mm during 1987 (Fig. 3).
Mean monthly temperatures range from 11 and $9.5^{\circ} \mathrm{C}$ (in January) to 27 , respectively; $27.5^{\circ} \mathrm{C}$ (in July). Evaporation was measured using the Colorado evaporation pan installed at Ghèzala dam. The annual total evaporation is $1518 \mathrm{~mm}$. It varies between 105 and $35 \mathrm{~mm}$ during September-October; 30-135 mm during March to May and 203-232 mm during June to August. Maximum evaporation $(262 \mathrm{~mm})$ is in July and minimum $(37 \mathrm{~mm})$ is in January. But since, precipitation is spread over almost 8 months; this area does not receive precipitation more than natural evaporation. Generally, annual evaporation is double the annual precipitation. During all months (except November to February), evaporation is more than the naturally occurring precipitation. On September and May, the deficit is quite appreciable from this count. The deficit will have to be partially made good by conserving water from ravine into collinear lakes at several places and by increasing mulching agricultural fields to prevent evaporation [12]. In particular, the building in Tunisia of small earth dams in underprivileged rural areas contributes to expansion of agriculture through 
Table 2 Monthly and seasonal distribution of annual rainfall at Ghèzala Dam station

\begin{tabular}{|c|c|c|c|c|c|c|c|c|c|c|c|c|c|}
\hline Month & Sept & Oct & Nov & Dec & Jan & Feb & March & Apr & May & June & July & Aug & Annual \\
\hline Average $(\mathrm{mm})$ & 44.2 & 75.2 & 96.9 & 105.5 & 96.3 & 94.4 & 61.3 & 54.4 & 27.1 & 12.1 & 3.3 & 8.8 & 679.5 \\
\hline$\%$ & 6.5 & 11.1 & 14.3 & 15.5 & 14.2 & 13.9 & 9 & 8 & 4 & 1.8 & 0.5 & 1.3 & 100 \\
\hline Coefficient of variation & 0.82 & 0.79 & 0.61 & 0.66 & 0.49 & 0.64 & 0.78 & 0.59 & 0.68 & 1.23 & 2.23 & 1.57 & 0.25 \\
\hline Season & Autumn & & & Winter & & & Spring & & & Summer & & & Annual \\
\hline Rainfall/season (mm) & 216.3 & & & 296.2 & & & 142.8 & & & 24.2 & & & 679.5 \\
\hline$\%$ & 31.8 & & & 43.6 & & & 21 & & & 3.6 & & & 100 \\
\hline
\end{tabular}

Fig. 3 Time series of annual rainfall (1968-2009) over Ghèzala Dam station

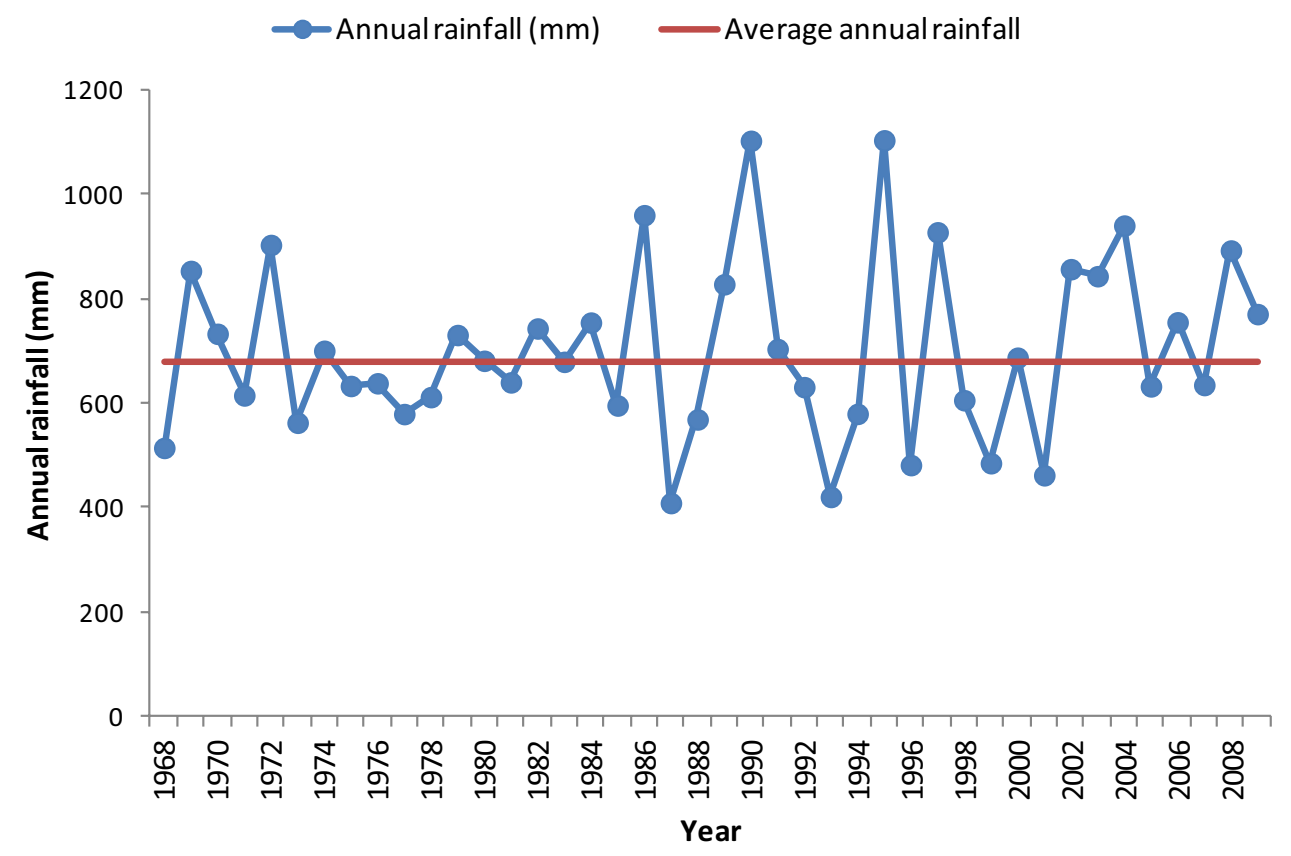

the development of irrigated areas and aquaculture, the watering of cattle. In addition, they contribute to the protection of large dams against premature siltation.

Daily rainfall data of five stations (Table 3 , Fig. 1 ) were collected from start activity until 2010. These stations were selected because they are the oldest in the region and are fairly evenly spread throughout the study region. These daily records were used in this subsequent analysis study.

\section{Method}

The methodology is based on the wet-dry spell approach. Dry spells consist of a series of dry days framed by wet events (Fig. 4). Therefore, the rainy season is defined as a succession of wet spells and dry spells [2]. The beginning of the first wet spell in autumn, in September, marks the beginning of the rainy season, whiles the end of the last wet spell in the spring (April) marks

Table 3 Rain gauge stations with geographical coordinates located in Ichkeul lake basin

\begin{tabular}{lllllrr}
\hline Order number & Code & Rain gauge station & X UTM $(\mathrm{m})$ & Y UTM $(\mathrm{m})$ & Altitude $(\mathrm{m})$ & Start activity \\
\hline 11 & $1,483,275,405$ & Fritissa & $554,782,832$ & $4,086,161,89$ & 248 & Mars-82 \\
12 & $1,483,287,805$ & Ghèzala Dam & $548,511,904$ & $4,101,153,63$ & 56 & Janv-68 \\
20 & $1,483,486,105$ & Wadi Joumine Antra & $541,463,714$ & $4,087,363,16$ & 230 & Janv-62 \\
27 & $1,483,597,005$ & Sidi Abdelbasset & $554,545,195$ & $4,083,990,82$ & 244 & Nov-86 \\
30 & $1,483,663,005$ & Sidi Salem & $548,164,87$ & $4,106,706,64$ & 15 & Sept-59 \\
\hline
\end{tabular}


Fig. 4 Representation of the climatic cycle. Legend: $m$ : the index $m$ refers to the $m$ th event (spell) of the $n$th rainy season; $D_{n, m}$ : duration of $m$ th wet (rainfall) spell in a $n$th rainy season symbolizing the number of subsequent rainy days; $H_{n, m}$ : total accumulated rainfall depth of $D_{n, m}$ rainy days in $\mathrm{mm}$; $h j$ : daily rainfall amounts; $j$ : the index $j$ refers to the $j$ th day. $Z_{n, m}$ : duration of $m$ th dry spell in a $n$th rainy season.

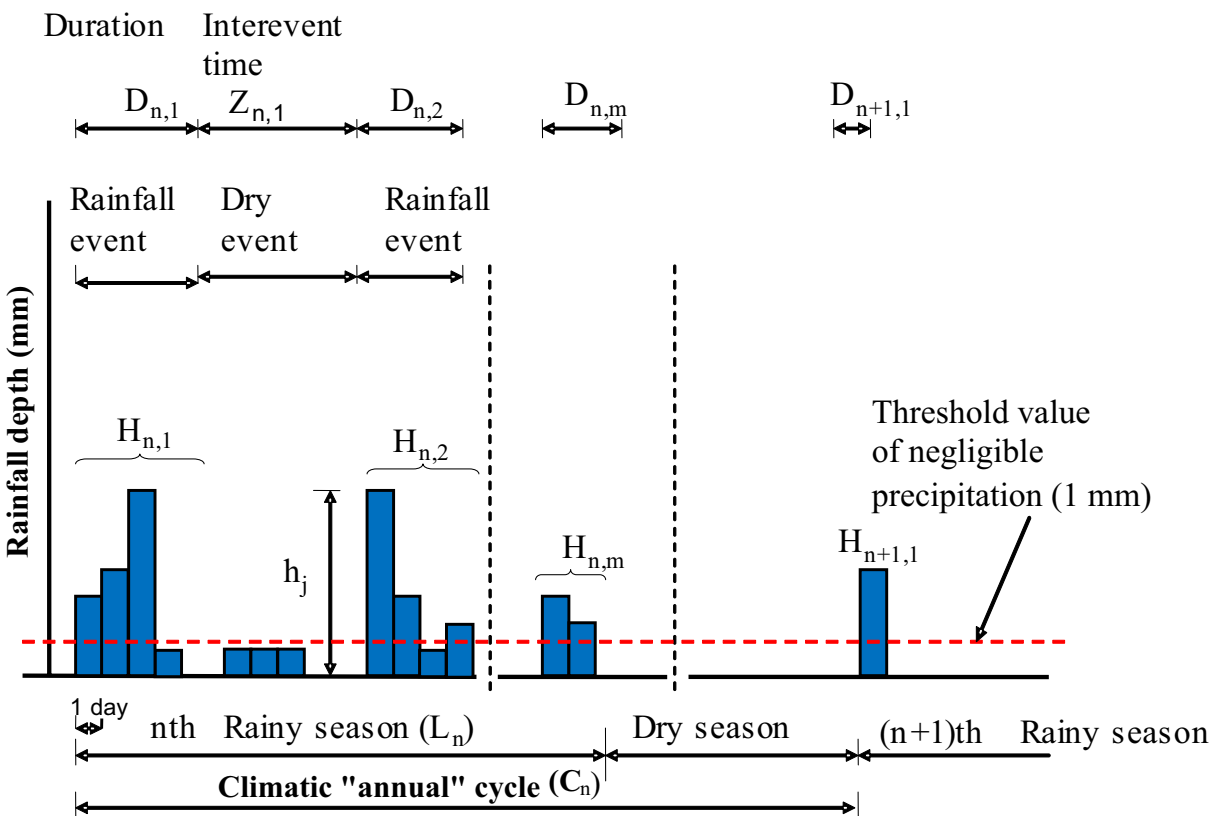

the end of the rainy season. The dry season therefore lasts about 4 months.

The wet events themselves are defined as an uninterrupted series of rainy days comprising at least one day having received a precipitation above a predetermined threshold value (Fig. 4) [2]. The definition of event is associated with a rainfall threshold value which defines wet. The limit $1 \mathrm{~mm}$ day $^{-1}$ has been selected because it corresponds approximately to the minimum daily evapotranspiration in Ichkeul lake Basin during the rainy season [18]. Thus, at least a daily precipitation will balance the minimum daily evapotranspiration.

$H_{n, m}$ is given by the following equation:

$H_{n, m}=\sum_{j=1}^{D n, m} h_{j}$

$h j$ stands for the daily rainfall totals in $\mathrm{mm}$. Note that $h j>0$ and that for at least one $h j>1 \mathrm{~mm}$.

The dry spell $Z_{n, m}$ represents the number of days between two subsequent wet spells. The length of the rainy season $L_{n}$ is defined as the time span between the onset of the first and the end of the last event of the given season; while the length of the climatic cycle is determined as the time elapsed between the onsets of two subsequent rainy seasons (Fig. 4).

\subsection{Identification of wet and dry spells}

As mentioned already a physic criterion has been developed and applied to identify wet and dry spells over the five rain gauge stations. Rainfall threshold used in the criterion is derived from local evaporation climatology that is daily mean evaporation (DME) over the area of interest [12]. Computational steps of the schemes are as follows: 1. Identification of dry spells (DS) and wet spells (WS) (Fig. 4). Rainy days with less than the threshold depth of precipitation are accounted for the wet spell if they occur in an uninterrupted sequence-Only isolated sub threshold rainfall will be discarded, and considered as part of a dry spell-A dry spell is assigned to month in which it started even if it continues in the following month or months; 2 . Calculation of duration, and rainfall amount of wet spells; 3 . Calculation of the number of wet spells per rainy season $n\left(M_{n}\right)$; 4. Deduction of the number of dry spells per rainy season $n\left(Z_{n}=M_{n}-1\right)$; Deduction of lengths of rainy season and climatic cycle; and 5. Identification of starting and ending date of rainy season.

Besides these, characteristics of important parameters (duration, number) of dry spells and wet spells duration and total accumulated rainfall depth per wet event, and his extremes in respect of yearly number of events; starting and ending date of rainy season have been studied in order to understand if there is any change taking place in the hydrological cycle of the area. All the parameters of the two elements wet and dry spells of the rainfall time distribution have been examined in this study. Description of spatial variation of dry spells, and rainfall amount of individual wet spell is given across the region.

\subsection{Trend analysis}

Statistically, trend is a significant change over time which is detectable by parametric and nonparametric procedures while trend analysis of a time series consists of the 
magnitude of trend and its statistical significance [19]. In this study the Mann-Kendall test was used to detect trends in the series of variables analyzed, and then the magnitude was examined by the nonparametric Sen's estimator method.

\subsubsection{Mann-Kendal test}

The nonparametric test, usually known as Kendall's $\tau$ statistics, $[20,21]$ is a widely used in hydrology and climatology to test randomness against trend of hydrologic time series $[19,22]$. This test is not affected by the actual distribution of the data and is less sensitive to outliers. Therefore, it is more suitable for detecting trends in climatic and hydrological data, which are usually skewed, and may contain outlier observations [22].

For any sample of $n$ variables, $x_{1}, \ldots, x_{n}$, the null hypothesis states that the sample is independent and identically distributed. The alternative hypothesis of a two-sided test is that the distributions of $x_{i}$ and $x_{j}$ are not identical for all $k, j \leq n$ with $i \neq j[23]$.

The MK test is based on test statistic $S$ defined as follows:

$S=\sum_{i=2}^{n} \sum_{j=1}^{i-1} \operatorname{sign}\left(x_{i}-x_{j}\right)$

, where the $x_{j}$ are the sequential data values, $n$ is the length of the time series, and sign $\left(x_{i}-x_{j}\right)$ is -1 for $\left(x_{i}-x_{j}\right)<0 ; 0$ for $\left(x_{i}-x_{j}\right)=0$, and 1 for $\left(x_{i}-x_{j}\right)>0$.

The mean $E[S]$ and variance $V[S]$ of the statistic $S$ may be given as follows:

$E \llbracket S \rrbracket=0$

$V \llbracket S \rrbracket=\frac{n(n-1)(2 n+5)-\sum_{p=1}^{q} t_{p}\left(t_{p}-1\right)\left(2 t_{p}+5\right)}{18}$,

where $t_{p}$ is the number of ties for the $p$ th value and $q$ is the number of tied values. The second term represents an adjustment for tied or censored data. The standardized test statistic $\left(Z_{\mathrm{MK}}\right)$ is computed by:

$Z_{\mathrm{MK}}=\left\{\begin{array}{cl}\frac{s-1}{\sqrt{\operatorname{Var}(S)}} & \text { if } S>0 \\ 0 & \text { if } S=0 \\ \frac{s+1}{\sqrt{\operatorname{Var}(S)}} & \text { if } S<0\end{array}\right.$

A positive $Z_{M K}$ indicates an increasing trend, whereas a negative $Z_{\mathrm{MK}}$ indicates a decreasing trend. To test for either increasing or decreasing monotonic trend at $p$ significance level, the null hypothesis is rejected if the absolute value of $Z$ is greater than $Z_{1-p / 2}$, where $Z_{1-p / 2}$ is obtained from the standard normal cumulative distribution tables. In this work, the significance level of $p=0.05$ is applied.
Table 4 Longest observed dry spell duration (day) at rain gauge stations (Ichkeul lake basin)

\begin{tabular}{llll}
\hline Rain gauge station & $\begin{array}{l}\text { Longest observed } \\
\text { dry spell (day) }\end{array}$ & $\begin{array}{l}\text { No. of dry } \\
\text { spells } \\
\text { (Sept-April) }\end{array}$ & Year \\
\hline Fritissa & 49 & 29 & 1982 \\
Ghèzala Dam & 41 & 32 & 1997 \\
Wadi Joumine Antra & 43 & 24 & 1988 \\
Sidi Abdelbasset & 46 & 20 & 1995 \\
Sidi Salem & 38 & 21 & 2008 \\
\hline
\end{tabular}

\subsubsection{Sen's estimator method}

We used Sen's nonparametric estimate of the slope to determine the magnitude of trends [24] of dry and wet spells time series data. The Sen's slope estimator method uses a linear model for the trend analysis. The slope $\left(T_{i}\right)$ of all data pairs is calculated using Eq. (6) by:

$T_{i}=\frac{x_{i}-x_{k}}{j-k} \quad$ for $i=1,2,3, \ldots n$,

where $x_{j}$ and $x_{k}$ are data values at time $j$ and $k(j>k)$ separately.

The median of these $n$ values of $T_{i}$ is represented by Sen's slope of estimation which is calculated using Eq. (7):

$Q_{i}= \begin{cases}T_{\frac{n+1}{2}} & \text { for } n \text { is odd } \\ \frac{1}{2}\left(T_{\frac{n}{2}}+T_{\frac{n+2}{2}}\right) & \text { for } n \text { is even }\end{cases}$

Sen's estimator $\left(Q_{\text {med }}\right)$ is calculated using above equation depending upon value of $n$ is either odd or even and then $\left(Q_{\text {med }}\right)$ is computed using $100(1-a) \%$ confidence interval using nonparametric test depending upon normal distribution. A positive value of $Q_{i}$ indicate increasing (upward) trend while negative value of $Q_{i}$ represent downward or decreasing trend of time series data.

\section{Results and discussion}

\subsection{Dry event analysis}

In planning studies the dry spells of maximum duration are of crucial importance. These values and number of dry spells recorded during rainy seasons were extracted from the event based analysis. Longest dry spell durations of five rain gauges for Ichkeul Lake Basin are given in Table 4. The number of dry spell ranges between 20 and 32 . Hence, supplementary irrigation iterations are required. The values in Table 4 show that out of 29 dry spells, there was a 49-day occurrence at Fritissa rain gauge station during 
Table 5 Crop calendar

\begin{tabular}{|c|c|c|c|c|c|c|c|c|c|c|c|c|}
\hline \multirow[t]{2}{*}{ Crops } & \multicolumn{12}{|c|}{ Month } \\
\hline & Sept & Oct & Nov & Dec & Jan & Feb & Mar & Apr & May & June & July & Aug \\
\hline \multicolumn{13}{|c|}{ Late seas. potato } \\
\hline \multicolumn{13}{|c|}{ Season potato } \\
\hline \multicolumn{13}{|c|}{ Green beans } \\
\hline \multicolumn{13}{|c|}{ Green bean } \\
\hline \multicolumn{13}{|l|}{ Sugar beet } \\
\hline \multicolumn{13}{|l|}{ Field peas } \\
\hline \multicolumn{13}{|l|}{ Artichoke } \\
\hline Sorghum & & & & & & & & & & & & \\
\hline
\end{tabular}

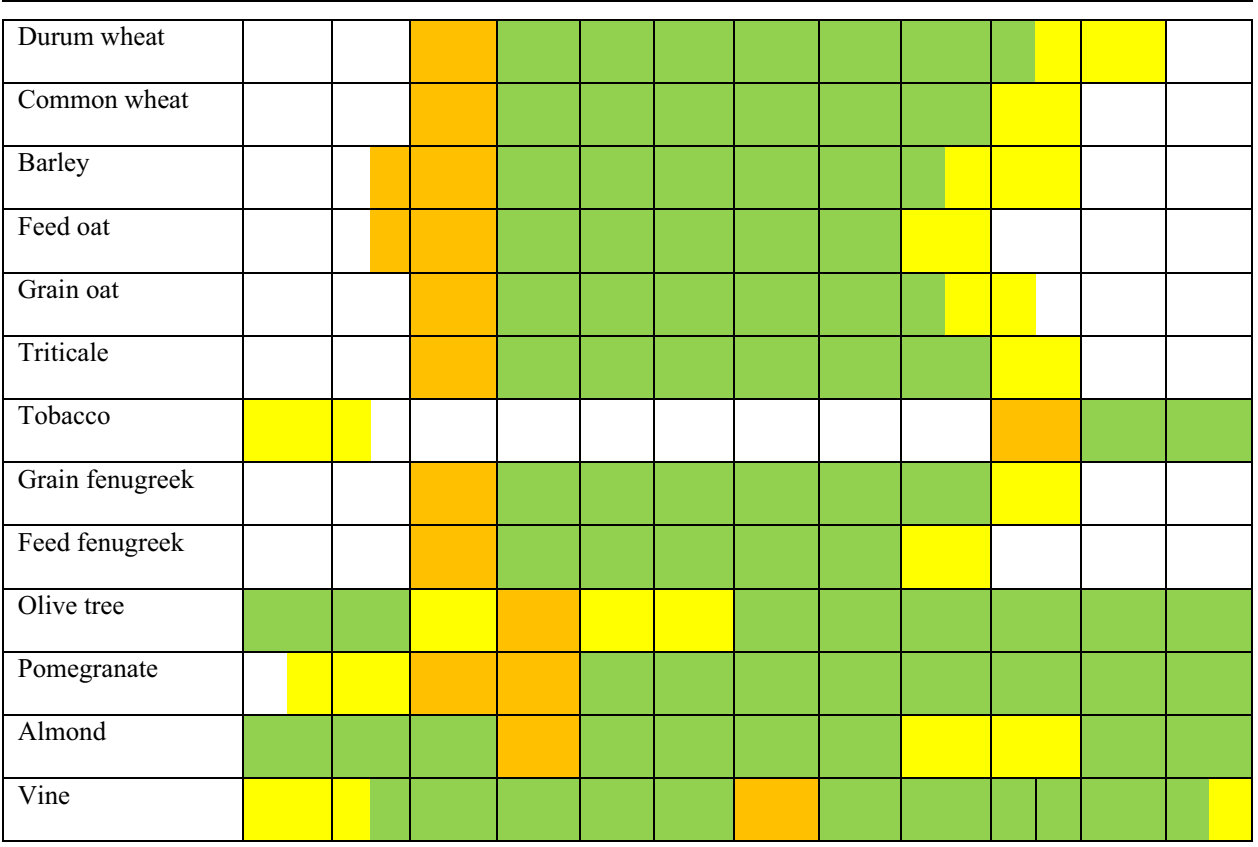

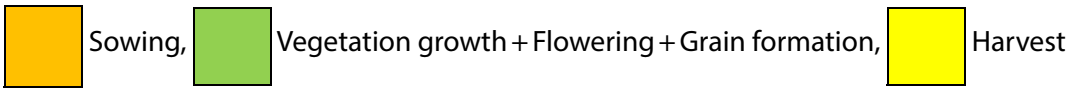

1982. The risk is very high; at least a dry spell of 38 days (more than one month) occurred in 2008 at Sidi Salem rain gauge station, with greater annual precipitation (Northern region of the watershed).

With reference to Table 4, it was observed that maximum dry spell (49 days) at Fritissa in 1982 and minimum 38 days at Sidi Salem in 2008. In order to set the crop planting and harvest of the main crops in the basin, the crop calendar was developed based on field surveys and internal reports of Agricultural Extension Services (Table 5). The knowledge of occurrence of the first wet spell in autumn is very important because it affects germination for autumn sowing. Already, the temporary interruption of the rainy season by a dry spell can damage crops, for example, if the dry spell occurs at the time of pollination or before the crops begin to ripen. Damage can occur even if the total seasonal precipitation is normal. Among others, dry spells have adverse consequences on the flow of the rivers. While consideration of past wet spells, the autumn season is postponed by one month (September to October) which is shown in crop calendar of Ichkeul lake basin (Table 5). Shifting of the entire cropping season by one month is affecting crop yield for various crops.

Analysis of maximum monthly dry spells is summarized in Table 6 and showed in Fig. 5. There is no statistical evidence that the average duration of this phenomenon is different in February, January or March. The mean maximum monthly dry spell during the core of the rainy season varies between 10 and 15 days. It is interesting to note that the length of dry spell in October, January and February at 
Table 6 Length of maximum monthly dry spell within the rainy season (Ichkeul lake basin)

Fig. 5 Maximum monthly dry spell recorded at each station within the rainy season

\begin{tabular}{llccccccc}
\hline Rain gauge station & Sept & Oct & Nov & Dec & January & Feb & March & April \\
\hline Fritissa & $(1) 17.2$ & 16.4 & 10.7 & 12.0 & 12.1 & 13.4 & 15.6 & 13.8 \\
& $(2) 10.51$ & 9.14 & 5.62 & 8.05 & 8.38 & 8.17 & 7.24 & 8.18 \\
& $(3) 0.61$ & 0.56 & 0.53 & 0.67 & 0.69 & 0.61 & 0.46 & 0.59 \\
Ghèzala Dam & $(1) 14.8$ & 14.5 & 10.1 & 11.1 & 11.7 & 11.1 & 13.2 & 14.7 \\
& $(2) 7.36$ & 7.47 & 5.09 & 5.40 & 6.80 & 7.38 & 6.04 & 8.66 \\
& $(3) 0.50$ & 0.52 & 0.51 & 0.49 & 0.58 & 0.66 & 0.46 & 0.59 \\
Wadi & $(1) 16.6$ & 14.3 & 11.3 & 12.1 & 10.5 & 11.9 & 12.5 & 10.8 \\
Joumine & $(2) 10.29$ & 8.33 & 7.24 & 6.98 & 5.86 & 7.58 & 6.62 & 6.56 \\
Antra & $(3) 0.62$ & 0.58 & 0.64 & 0.58 & 0.56 & 0.64 & 0.53 & 0.61 \\
Sidi Abdelbasset & $(1) 17.1$ & 16.6 & 12.0 & 11.9 & 14.1 & 15.1 & 14.2 & 14.3 \\
& $(2) 10.68$ & 8.80 & 6.48 & 5.71 & 11.23 & 10.27 & 7.15 & 7.87 \\
& $(3) 0.63$ & 0.53 & 0.54 & 0.48 & 0.80 & 0.68 & 0.50 & 0.55 \\
Sidi Salem & $(1) 17.5$ & 13.5 & 10.3 & 11.8 & 11.8 & 11.8 & 15.5 & 9.9 \\
& $(2) 9.15$ & 7.58 & 5.58 & 7.02 & 6.34 & 7.28 & 8.95 & 6.82 \\
& $(3) 0.52$ & 0.56 & 0.54 & 0.60 & 0.54 & 0.62 & 0.58 & 0.69 \\
\hline
\end{tabular}

1. Mean; 2. Standard deviation; 3. Coefficient of variation

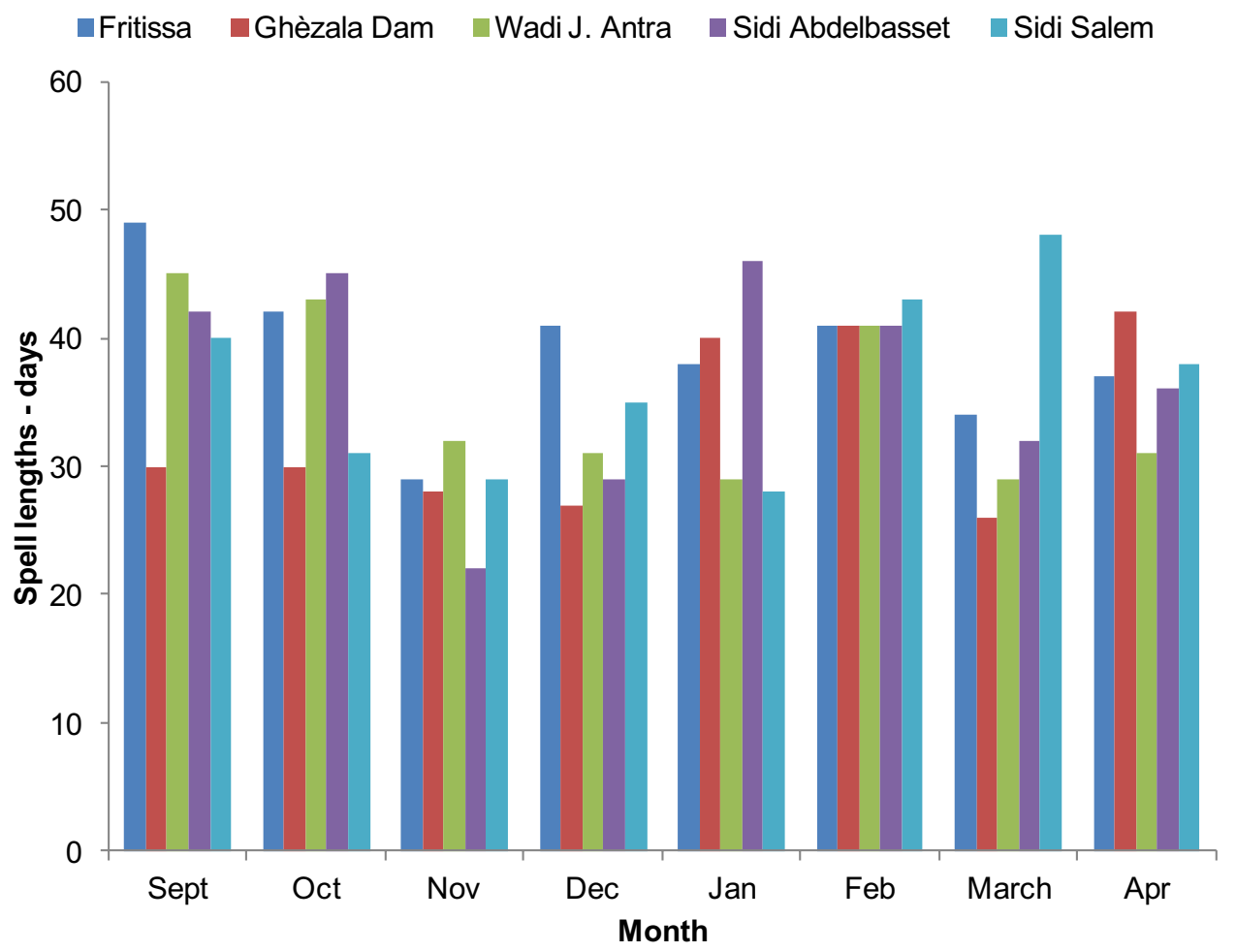

Sidi Abdelbasset is greater than for the other rainfall stations in Table 6. In fact, this station is situated in semi-arid region of the basin. This phenomenon can come also from the bias due to a short observation period. It can be seen that the dry spell seem to show randomness throughout the rainy season from September to April.
The effects of climate on drought duration were studied by statistical analysis. Short droughts lasting less than 3 days have been discarded. Subsequently, the mean, maximum and standard deviation statistics were calculated for the variable duration of dry spells (Table 7).

By comparing the dry spells between stations, Table 7 shows a small difference between dry spells 
Table 7 General drought characteristics using a $1 \mathrm{~mm}$ threshold (based on a precipitation analysis), and a minimum duration of 3 days for the hydrometeorological variables

\begin{tabular}{llll}
\hline Rain gauge station & $\begin{array}{l}\text { No. of droughts } \\
\text { (per year) }\end{array}$ & $\begin{array}{l}\text { Mean } \\
\text { duration } \\
\text { (day) }\end{array}$ & $\begin{array}{l}\text { Max duration } \\
\text { (day) }\end{array}$ \\
\hline Fritissa & 18.3 & 8.9 & 49 \\
Ghèzala Dam & 22.4 & 7.8 & 42 \\
Wadi Joumine Antra & 17.3 & 8.3 & 45 \\
Sidi Abdelbasset & 18.1 & 9 & 46 \\
Sidi Salem & 17.1 & 8.5 & 48 \\
\hline
\end{tabular}

number (around 5.3 per year) and average duration (around 1.2 days) of meteorological droughts. The significant difference is recorded between Sidi Abdelbasset and Ghèzala Dam, respectively, 18 droughts per year with an average duration of 9 days and 22 droughts per year with an average duration of 7.8 days. This difference is affected by the variability in precipitation. On that point, Sidi Abdelbaset is characterized by less dry spells but longer, while in Ghèzala dam, the highest number of short dry spells reflects greater rainfall variability. The longest drought occurs at Fritissa (49 days, more than 1.5 months). By examining the data in Table 6 , it is concluded that the average drought duration are a first indication of the water deficit that plants may suffer from it, and that this drought duration might have different governing factors.

We conducted a linear regression model analysis to identify the trends in the basin. Figure 6 shows the number of drought affected Ichkeul lake basin. The regression trend lines are also given in this figure. Overall, the number of dry spell in the study area was increasing except
Table 8 Trends test thresholds for the annual number of dry spells. Level of significance alpha threshold $=0.05$

\begin{tabular}{lccc}
\hline Rain gauge station/test & Kendall statistic & $p$ Value & Sen's slope \\
\hline Fritissa & 0.056 & 0.704 & 0 \\
Ghèzala Dam & -0.45 & 0.001 & -0.217 \\
Wadi Joumine Antra & 0.231 & 0.107 & 0.02 \\
Sidi Abdelbasset & 0.081 & 0.1 & 0.08 \\
Sidi Salem & 0 & 1 & 0 \\
\hline
\end{tabular}

for Ghèzala-Dam (Fig. 6). The number of drought affected basin is reported more in Ghèzala Dam and few number of drought affected Sidi Salem station. Most number of droughts affected Ghèzala Dam is observed in 1982, 1985, 1987, 1989 to 1991 , and 1995 to 1997 over Ichkeul lake basin (Fig. 6).

According to data from the General Directorate of Water Resources in Tunisia, recently, severe drought has been experienced in this region during September 2015 to September 2018, and indeed throughout the country, where surface water resources were almost entirely committed to human consumptive uses, groundwater exploited intensively and the discharge to the sea almost nil. During the entire operation period of the stations, a significant increase in the severity of droughts was reported over Ichkeul lake basin during the period of 1960-1961, 1968-1969, 1994, 2015-2016 and 2016-2017.

Analysis carried out on the dry spells number is conducted in order to reflect the dry spells severity in this area. A conditioned number-duration by splitting the dry spell duration into different classes was performed
Fig. 6 Tends of annual number of drought affected stations in Ichkeul lake basin

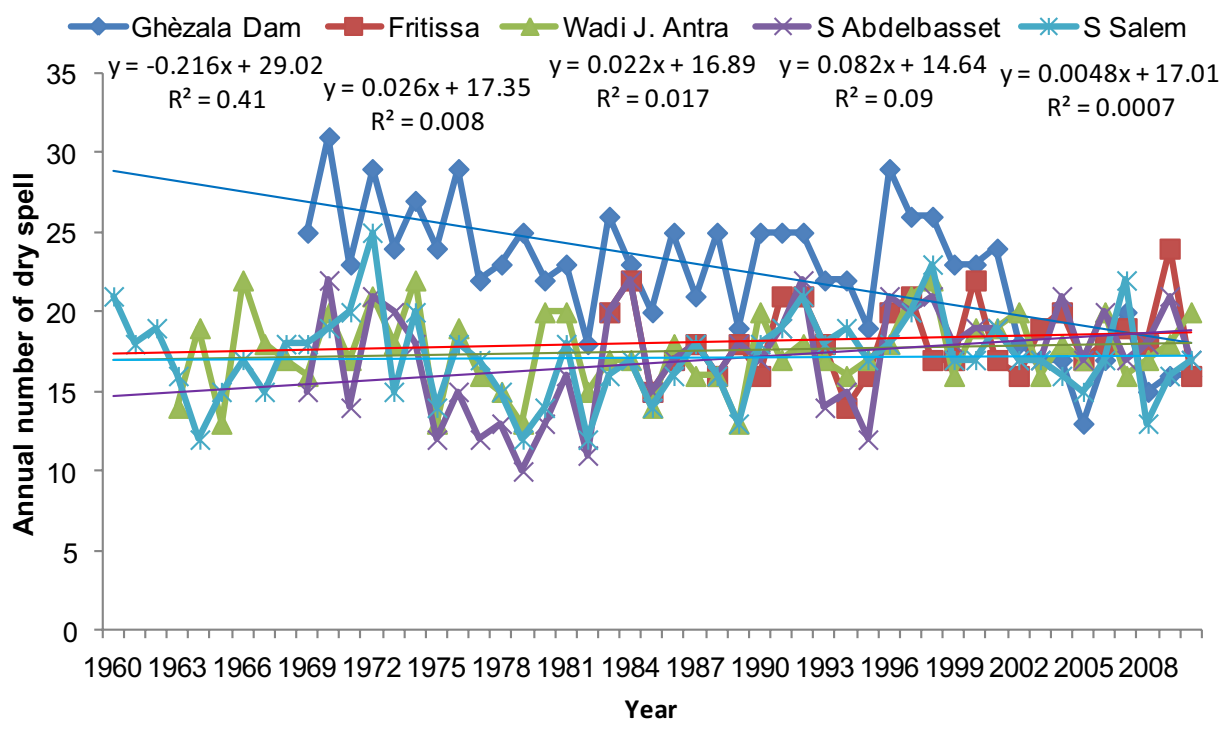


Table 9 Trends in the monthly extreme dry spell length. Signification level (\%): 5, (Sen's slope): 95\%

\begin{tabular}{llrrrrrrrr}
\hline Rain gauge station & Test & Sep & Oct & Nov & Dec & Jan & Feb & Mar & Apr \\
\hline Fritissa & Kendall statistic & -0.416 & -0.059 & 0.071 & 0.064 & -0.026 & 0.029 & 0.274 & -0.044 \\
& $p$ Value & 0.005 & 0.677 & 0.619 & 0.660 & 0.867 & 0.850 & 0.049 & 0.770 \\
& Sen's slope & -0.739 & -0.114 & 0.051 & 0.050 & 0 & 0 & 0.353 & -0.048 \\
Ghèzala Dam & Kendall statistic & -0.118 & 0.021 & -0.054 & -0.109 & 0.026 & 0.029 & 0.235 & -0.044 \\
& $p$ Value & 0.287 & 0.853 & 0.632 & 0.327 & 0.819 & 0.804 & 0.034 & 0.695 \\
Wadi Joumine Antra & Ken's slope & -0.083 & 0 & 0 & -0.071 & 0 & 0 & 0.167 & 0 \\
& Kendall statistic & -0.128 & 0.103 & -0.042 & 0.036 & 0.037 & 0.103 & 0.224 & 0.098 \\
& $p$ Value & 0.241 & 0.324 & 0.697 & 0.740 & 0.732 & 0.332 & 0.034 & 0.356 \\
Sidi Abdel Basset & Sen's slope & -0.129 & 0.083 & 0 & 0 & 0 & 0.048 & 0.156 & 0.038 \\
& Kendall statistic & 0.009 & -0.271 & 0.190 & 0.022 & 0.041 & 0.122 & 0.171 & 0.224 \\
& $p$ Value & 0.965 & 0.048 & 0.171 & 0.889 & 0.781 & 0.391 & 0.225 \\
Sidi Salem & Sen's slope & 0 & -0.231 & 0.125 & 0 & 0 & 0.104 \\
& Kendall statistic & -0.182 & 0.095 & -0.029 & 0.006 & -0.090 & -0.028 & 0.113 & 0.048 \\
& $p$ Value & 0.091 & 0.354 & 0.775 & 0.961 & 0.374 & 0.782 & 0.254 & 0.643 \\
& Sen's slope & -0.158 & 0.064 & 0 & 0 & -0.045 & 0 & 0.077 & 0 \\
\hline
\end{tabular}

by Mathlouthi and Lebdi [25]. In fact, the results analysis has shown that a short to medium duration year can have a significant number of dry spells, without denying that there can be dry spell of long duration. Thus, dry spells occur randomly during the rainy season Mathlouthi and Lebdi [25].

Overall, the annual number of dry spells in Ghèzala Dam significantly decreased, with a rate of $0.217 /$ year $(p=0.001)$. In other stations (Fritissa, Wadi Joumine Antra, Sidi Abdelbasset, Sidi Salem) the trend is not significant at $5 \%$ (Table 8 ).

Table 9 shows the Mann-Kendall statistics for monthly extreme dry spell length and related $p$-values. From this table, it is clear that three stations, Fritissa, Ghèzala Dam and Wadi Joumine Antra, have a positive trend at $5 \%$ significant level with, respectively, a rate of 3.53 days $/ 10$ years $(p=0.049), 1.67$ days $/ 10$ years $(p=0.034)$ and 1.56 days $/ 10$ years $(p=0.034)$, in March included growing season. This may show that the monthly extreme dry spell length have changed in recent years over Ichkeul lake basin for three stations. It should also be noted that Fritissa and Wadi Joumine Antra stations are located, respectively, in South East semi-arid region and south west sub-humid regions of the basin.

In Table 9, two stations have significant trend, among which, one station shows a negative trend at $5 \%$ significant level with a rate of -7.39 days $/ 10$ years $(p=0.005)$ in September (Fritissa), and one station shows a negative trend at $5 \%$ significant level with a rate of -2.31 days $/ 10$ years $(p=0.048)$ in October (Sidi Abdelbasset).

This section presents the nonparametric Mann-Kendall test results for monthly dry spell length. Regarding
Table 10, as already mentioned each dry spell is assigned to the month in which it started. From Table 10, it is clear that two stations, Fritissa and Sidi Salem, have a negative trend at $5 \%$ significant level on September. This may shows that the monthly dry spell length has not changed in September except for two stations. Sidi Abdelbasset station shows a positive trend at $5 \%$ significant level in October (autumn season) and February and March (growing crop season).

\subsection{Wet spell analysis}

The exploratory data analysis is based on the calculation of data descriptive statistics. Table 11 shows observation number, maximum, average, and standard deviation of the selected variables. The average rainfall duration of Ichkeul Lake basin is 2.19 days and the average rainfall amount is $21.01 \mathrm{~mm}$ (Sidi Salem). Maximum seasonal rainfall number are observed at Ghèzala dam (30 events) and Wadi Joumine Antra (29 events) stations in center region of the basin, whereas the minimum seasonal rainfall number ( 23 events) belong to Sidi Abdelbasset station in south semi-arid region of the basin.

In order to understand the adequacy of precipitation during the first to 39th meteorological week for rainfed cultivation, a weekly analysis of precipitation during the rainy season (September-April) was carried out (Table 12). Calculus show that $20 \mathrm{~mm}$ of rainfall in week will be able to meet 0.54-0.75 times the evaporation demand, at the onset or end of the growing season. Allen et al. [26] stipulate that during the early stages of growth, the crop water requirement will be about 0.7 of the evaporation demand 
and would increase during the reproductive stage of crop growth.

Longest observed wet spells in Ichkeul lake basin are given in Table 13. The number of wet spells varies between 24 and 32. From Table 13, it is quite clear that the longest wet spells are related to the annual total precipitation. The longest rainfall event was recorded in Sidi Salem rain gauge in 1962; 17 days resulting in $122 \mathrm{~mm}$. The shortest is observed in Sidi Abdelbasset in 2002 with low annual precipitation; i.e., 10 days with an accumulation of $63.5 \mathrm{~mm}$.

Table 14 reports the Mann-Kendall test results for the wet spells duration, rainfall amount and seasonal number during the rainy season. From this table, we can see that for the wet spells duration the trend is significant for Sidi
Abdelbasset and Sidi Salem stations with a Sen's slope of 0 ( $p=0.001$ and $<0.0001$, respectively). At Sidi Abdelbasset station, the trend of the rainfall amount per wet spell is significant, but the Sen's slope is null $(p=0.012)$. A negative trend for the seasonal rainfall number is observed in two stations (Ghèzala Dam and Sidi Salem stations) with respective slopes of -0.217 and -0.111 .

\subsection{Rainy season and climatic cycle length}

Table 15 shows the main statistics of rainy season and climatic cycle lengths. From this table, we conclude that the average length of the rainy season differs slightly among stations. About the maximum, Fritissa records 258 days

Table 10 Trends in the monthly dry spell length. Signification level (\%): 5, (Sen's slope): 95\%

\begin{tabular}{|c|c|c|c|c|c|c|c|c|c|}
\hline Rain gauge station & Test & Sep & Oct & Nov & Dec & Jan & Feb & Mar & Apr \\
\hline \multirow[t]{3}{*}{ Fritissa } & Kendall statistic & -0.195 & 0.043 & -0.027 & -0.020 & -0.092 & 0.097 & 0.082 & -0.033 \\
\hline & $p$ Value & 0.026 & 0.611 & 0.762 & 0.827 & 0.300 & 0.274 & 0.352 & 0.713 \\
\hline & Sen's slope & -0.077 & 0 & 0 & 0 & 0 & 0 & 0 & 0 \\
\hline \multirow[t]{3}{*}{ Ghèzala Dam } & Kendall statistic & -0.098 & 0.057 & 0.052 & 0.003 & 0.068 & 0.067 & 0.078 & 0.060 \\
\hline & $p$ Value & 0.132 & 0.384 & 0.439 & 0.964 & 0.310 & 0.311 & 0.238 & 0.360 \\
\hline & Sen's slope & 0.011 & 0 & 0 & 0 & 0 & 0 & 0 & 0 \\
\hline \multirow[t]{3}{*}{ Wadi Joumine Antra } & Kendall statistic & -0.096 & 0.017 & 0.036 & 0.092 & 0.073 & -0.002 & -0.025 & -0.038 \\
\hline & $p$ Value & 0.183 & 0.818 & 0.628 & 0.216 & 0.327 & 0.984 & 0.737 & 0.609 \\
\hline & Sen's slope & -0.021 & 0 & 0 & 0 & 0 & 0 & 0 & 0 \\
\hline \multirow[t]{3}{*}{ Sidi Abdelbasset } & Kendall statistic & 0.111 & 0.163 & 0.039 & 0.150 & 0.151 & 0.220 & 0.166 & -0.009 \\
\hline & $p$ Value & 0.173 & 0.042 & 0.633 & 0.068 & 0.065 & 0.008 & 0.043 & 0.919 \\
\hline & Sen's slope & 0.018 & 0.048 & 0 & 0.017 & 0.020 & 0.031 & 0.022 & 0 \\
\hline \multirow[t]{3}{*}{ Sidi Salem } & Kendall statistic & -0.141 & 0.057 & -0.076 & 0.119 & 0.064 & -0.031 & 0.021 & 0.043 \\
\hline & $p$ Value & 0.034 & 0.398 & 0.265 & 0.080 & 0.351 & 0.652 & 0.763 & 0.528 \\
\hline & Sen's slope & -0.034 & 0 & 0 & 0 & 0 & 0 & 0 & 0 \\
\hline
\end{tabular}

Table 11 Descriptive statistics of selected variables of rainfall spell

\begin{tabular}{|c|c|c|c|c|c|c|c|c|c|c|c|c|}
\hline \multirow[t]{2}{*}{ Rain gauge station } & \multicolumn{4}{|c|}{ Rainfall duration } & \multicolumn{4}{|c|}{ Rainfall amount } & \multicolumn{4}{|c|}{ Seasonal rainfall number } \\
\hline & Obs & Max (day) & Mean (day) & SD (day) & Obs & $\operatorname{Max}(\mathrm{mm})$ & Mean (mm) & $\mathrm{SD}(\mathrm{mm})$ & Obs & Max & Mean & SD \\
\hline Fritissa & 802 & 11 & 1.95 & 1.36 & 802 & 188.5 & 18.85 & 21.79 & 28 & 25 & 19.32 & 2.46 \\
\hline Ghèzala Dam & 984 & 13 & 2.93 & 2.27 & 984 & 182.8 & 24.37 & 29.32 & 42 & 30 & 22.04 & 4.41 \\
\hline Wadi Joumine Antra & 1355 & 16 & 2.28 & 1.72 & 1355 & 199.6 & 22.59 & 28.09 & 48 & 29 & 19.54 & 2.97 \\
\hline Sidi Abdelbasset & 839 & 10 & 1.67 & 1.10 & 839 & 149 & 14.53 & 17.26 & 24 & 23 & 19.09 & 2.52 \\
\hline Sidi Salem & 1477 & 17 & 2.19 & 1.69 & 1477 & 180.5 & 21.01 & 24.61 & 51 & 24 & 18.81 & 2.28 \\
\hline
\end{tabular}

Obs observation, Max maximum, SD standard deviation

Table 12 Weekly evaporation-weekly precipitation ratio of $20 \mathrm{~mm}$ at Ichkeul lake basin

SN Applied Sciences

\begin{tabular}{lcccccccc}
\hline Calculated parameters & Sept & Oct & Nov & Dec & Jan & Feb & March & April \\
\hline Weekly mean evaporation $E(\mathrm{~mm})$ & 38.9 & 24.8 & 14.9 & 10.7 & 10.2 & 11.7 & 19.8 & 26.4 \\
Weekly rainfall of $20 \mathrm{~mm}$ recorded $R(\mathrm{~mm})$ & 21.2 & 19.9 & 19.6 & 21.0 & 21.1 & 20.2 & 20.3 & 19.7 \\
$R / E$ & 0.54 & 0.80 & 1.32 & 1.96 & 2.07 & 1.73 & 1.03 & 0.75 \\
\hline
\end{tabular}


Table 13 Longest observed wet spell duration (day) at rain gauge stations (Ichkeul lake basin)

\begin{tabular}{lllll}
\hline Rain gauge station & $\begin{array}{l}\text { Longest observed wet } \\
\text { spell duration (day) }\end{array}$ & $\begin{array}{l}\text { Rainfall depth per } \\
\text { event }(\mathrm{mm})\end{array}$ & $\begin{array}{l}\text { No. of wet spell } \\
\text { events (Sept-April) }\end{array}$ & Year \\
\hline Fritissa & 11 & 82 & 24 & 1992 \\
Ghèzala Dam & 13 & 86.5 & 33 & 2009 \\
Wadi Joumine Antra & 16 & 143.7 & 24 & 1965 \\
Sidi Abdelbasset & 10 & 63.5 & 32 & 2002 \\
Sidi Salem & 17 & 122.1 & 26 & 1965 \\
\hline
\end{tabular}

and Sidi Abdelbasset scores 241 days. It appears that onset or end of the rainy season can move several weeks. The arithmetic mean of the climatic cycle length (Table 15) confirms the annual character for this climatic parameter. However, extreme lengths exceeding 400 days can be observed ( 445 days at Sidi Salem station). Table 16 shows there is no tend for these two seasonal parameters at $5 \%$ significance level.

\subsection{Start and end of rainy season}

The variability of start of the rainy season is similar for pairs of stations Ghèzala dam, Wadi Joumine Antra and Sidi Abdelbasset, Sidi Salem (Table 17). There is no variation for the end of the rainy season at all stations. Concerning the average, the rainy season (or climatic cycle) starts at mid-September in Fritissa, Wadi Joumine Antra and Sidi Salem and ends earlier at the end of April (Table 17). At Fritissa, Wadi Joumine Antra and Sidi Salem the rainy season starts on 14 September and ends, respectively, on 30,
27 and 23 April (Table 17) giving an average season length of 228,225 and 221 days.

The statistics of the results obtained showed that the shortest season in Fritissa was in 2005/2006 when the wet season ended early on March 24 (day 192) (Table 18).

Being in the drier part of the transect, the wet season at Fritissa and Sidi Abdelbasset stations ends earlier than the other stations along the transect. This confirms the results from Mupangwa et al. [27] who showed that as aridity increases, the season starts late and ends early. However, the size of the observation series is much shorter for these two stations to be able to consolidate these results. The most brutal end of the season in Sidi Abdelbasset was recorded on April 9.

The latest end of the wet season was recorded in $1968 / 69$ and occurred on May 5. This analysis shows, among other things, that the abrupt end of the rainy seasons observed is in agreement with the observations made in semi-arid southern Ichkeul lake basin during the $1982 / 83$ rainy season. The $1982 / 83$ rainy season ended on April 2, 1983 (in southern region).
Table 14 Trends in the wet spells parameters

\begin{tabular}{llllc}
\hline Rain gauge station & Test & $\begin{array}{l}\text { Rainfall duration } \\
(\text { day })\end{array}$ & $\begin{array}{l}\text { Rainfall amount } \\
(\mathrm{mm})\end{array}$ & $\begin{array}{l}\text { Seasonal } \\
\text { rainfall } \\
\text { number }\end{array}$ \\
\hline Fritissa & Kendall statistic & 0.001 & 0.020 & 0.114 \\
& $p$ Value & 0.967 & 0.436 & 0.493 \\
Ghèzala Dam & Sen's slope & 0 & 0 & 0.059 \\
& Kendall statistic & 0.042 & 0.045 & -0.579 \\
Wadi Joumine Antra & $p$ Value & 0.330 & 0.259 & 0.001 \\
& Sen's slope & 0 & 0.001 & -0.217 \\
& Kendall statistic & 0.005 & 0.024 & 0.075 \\
Sidi Abdelbasset & $p$ Value & 0.810 & 0.216 & 0.666 \\
& Sen's slope & 0 & 0 & 0 \\
& Kendall statistic & 0.100 & 0.054 & 0.087 \\
Sidi Salem & $p$ Value & 0.001 & 0.012 & 0.1 \\
& Sen's slope & 0 & 0 & 0.08 \\
& Kendall statistic & 0.092 & 0.013 & -0.311 \\
& $p$ Value & $<0.0001$ & 0.483 & 0.048 \\
& Sen's slope & 0 & 0 & -0.111 \\
\hline
\end{tabular}

Signification level (\%): 5, Confidence interval (\%) (Sen's slope): 95\% 
Table 15 Descriptive statistics of rainy season variables

\begin{tabular}{|c|c|c|c|c|c|c|c|c|}
\hline \multirow[t]{2}{*}{ Rain gauge station } & \multicolumn{4}{|c|}{ Rainy season length } & \multicolumn{4}{|c|}{ Climatic cycle length } \\
\hline & Obs & $\begin{array}{l}\text { Max } \\
\text { (day) }\end{array}$ & $\begin{array}{l}\text { Mean } \\
\text { (day) }\end{array}$ & $\begin{array}{l}\text { SD } \\
\text { (day) }\end{array}$ & Obs & $\begin{array}{l}\text { Max } \\
\text { (day) }\end{array}$ & $\begin{array}{l}\text { Mean } \\
\text { (day) }\end{array}$ & $\begin{array}{l}\text { SD } \\
\text { (day) }\end{array}$ \\
\hline Fritissa & 28 & 258 & 228.8 & 13.76 & 28 & 398 & 365.7 & 17.68 \\
\hline Ghèzala Dam & 42 & 254 & 237.9 & 13.03 & 42 & 378 & 365.4 & 9.34 \\
\hline Wadi Joumine Antra & 48 & 246 & 225.4 & 14.12 & 48 & 398 & 364.5 & 16.84 \\
\hline Sidi Abdelbasset & 24 & 241 & 227.1 & 12.27 & 24 & 397 & 363.3 & 19.02 \\
\hline Sidi Salem & 51 & 246 & 221.5 & 20.44 & 51 & 445 & 362.3 & 32.19 \\
\hline
\end{tabular}

Obs observation, Max maximum, SD standard deviation
Table 16 Trends in the rainy season and climatic cycle length

\begin{tabular}{llcc}
\hline Rain gauge station & Test & $\begin{array}{c}\text { Rainy sea- } \\
\text { son length }\end{array}$ & $\begin{array}{l}\text { Climatic } \\
\text { cycle } \\
\text { length }\end{array}$ \\
\hline Fritissa & Kendall statistic & 0.257 & -0.012 \\
& $p$ Value & 0.095 & 0.958 \\
& Sen's slope & 0.002 & 0 \\
Ghèzala Dam & Kendall statistic & -0.022 & 0.068 \\
& $p$ Value & 1 & 0.857 \\
Wadi Joumine Antra & Sen's slope & -0.001 & 0.001 \\
& Kendall statistic & 0.072 & -0.037 \\
& $p$ Value & 0.521 & 0.744 \\
Sidi Abdelbasset & Sen's slope & 0 & 0 \\
& Kendall statistic & -0.004 & 0.084 \\
& $p$ Value & 1 & 0.597 \\
Sidi Salem & Sen's slope & 0 & 0 \\
& Kendall statistic & 0.113 & -0.027 \\
& $p$ Value & 0.276 & 0.798 \\
& Sen's slope & 0 & 0 \\
\hline
\end{tabular}

Signification level (\%): 5, Confidence interval (\%) (Sen's slope): 95\%

It is also noted that the start of the rainy season is more variable in Fritissa, Sidi Abdelbasset and Sidi Salem than its end (Table 17). In our study, the farmers of Fritissa are faced with the prospects of a shorter rainy season compared to those of the Ghèzala dam, as it happens that the wet season did not start until September 13 and ended early on March 24; either giving a duration of only 190 days.

\subsection{Relationships of rainy season characteristics}

The linear regression model was applied to establish a linear relationship between the different characteristics of the rainy season in Ichkeul lake basin. Correlation analysis indicated that there is no significant relationship between the start and end of the rainy season (Table 19). A great relationship between the start and the duration of the rainy season was found (Table 19). The gradient in the relationship between the start and the end of the rainy season is most pronounced at Sidi Abdelbasset station, which implies that a delayed start of the season is probably followed by an early cessation of the rainy season. This station is located in the southern watershed, where the climate is semi-arid.

In Sidi Abdelbasst, the linear relationship between the start of the rainy season and the length of the climatic cycle is significant. The linear relationship suggests that a longer climate cycle translate into an early rainy season. This result provides an additional tool for characterizing climatic zones.

Table 17 Mean and median dates for the start and end of the rainy season in Ichkeul lake basin

\begin{tabular}{|c|c|c|c|c|c|c|c|c|}
\hline \multirow{2}{*}{$\begin{array}{l}\text { Station } \\
\text { Rain gauge Station }\end{array}$} & \multicolumn{4}{|l|}{ Start } & \multicolumn{4}{|l|}{ End } \\
\hline & Mean start date & Median start date & $\begin{array}{l}\text { Standard } \\
\text { deviation } \\
\text { (days) }\end{array}$ & $\mathrm{CV}$ & Mean end date & Median end date & $\begin{array}{l}\text { Standard } \\
\text { deviation } \\
\text { (days) }\end{array}$ & CV \\
\hline Fritissa & 14 September & 9 September & 12.73 & 0.91 & 30 April & 29 April & 4.79 & 0.02 \\
\hline Ghèzala Dam & 8 September & 8 September & 6.9 & 0.80 & 4 May & 6 May & 12.9 & 0.05 \\
\hline Wadi Joumine Antra & 14 September & 13 September & 11.62 & 0.82 & 27 April & 29 April & 5.47 & 0.02 \\
\hline Sidi Abdelbasset & 12 September & 7 September & 12.68 & 1.05 & 27 April & 27 April & 4.86 & 0.02 \\
\hline Sidi Salem & 14 September & 8 September & 16.3 & 1.11 & 23 April & 26 April & 7.2 & 0.03 \\
\hline
\end{tabular}


Table 18 Dates for the earliest and most delayed start and end of the rainy season along the Ichkeul lake basin

\begin{tabular}{lllll}
\hline Station & Earliest start & Most delayed start & Earliest end & Most delayed end \\
\hline Fritissa & 13 September & 6 October & 24 March & 30 April \\
Ghèzala Dam & 1 September & 1 October & 6 April & 5 May \\
Wadi Joumine Antra & 1 September & 9 October & 10 April & 5 May \\
Sidi Abdelbasset & 1 September & 3 October & 5 April & 30 April \\
Sidi Salem & 1 September & 27 November & 10 April & 5 May
\end{tabular}

\section{Discussion and conclusions}

A set of five rain gauges in Ichkeul lake basin Northern Tunisia with daily rainfall recording for at least 28 years has facilitated a detailed analysis of the chorological spatial patterns of trends of dry and wet spell magnitudes. The length of dry spell in October, January and February at Sidi Abdelbasset is greater than for the other rainfall stations. This station is situated in semi-arid region of the basin, and this phenomenon can come also from the bias due to a short observation period. By comparing the dry spells between stations, a small difference between dry spells number (around 5.3 per year) and average duration (around 1.2 days) of droughts is showed. The significant difference affected by the variability in precipitation is recorded between Sidi Abdelbasset and Ghèzala Dam. Sidi Abdelbaset is characterized by less dry spells but longer, while in Ghèzala dam, the highest number of short dry spells reflects greater rainfall variability. The longest drought occurs at Fritissa (49 days). The number of dry spell in the study area was increasing except for GhèzalaDam generated by a small variation in annual rainfall $(C V=0.25)$. The annual number of dry spells in Ghèzala Dam significantly decreased, with a rate of $0.217 /$ year $(p=0.001)$. In other stations, the trend is not significant at $5 \%$.

Focusing on the monthly extreme dry spell duration, Fritissa, Ghèzala Dam and Wadi Joumine Antra stations have a positive trend at $5 \%$ significant level with,
Table 19 Relationships of the different characteristics of the rainy season in Ichkeul lake basin

\begin{tabular}{lll}
\hline Station & Relationship & $R^{2}$ value \\
\hline Fritissa & Start and end & 0.001 \\
& Start and length of rainy season & 0.880 \\
& Start and number of wet days per-season & 0.001 \\
& Start and length of climatic cycle & 0.358 \\
Nhèzala Dam & Number of wet days and length of rainy season & 0.013 \\
& Start and end & 0.059 \\
Start and length of rainy season & 0.851 \\
Start and length of climatic cycle & 0.454 \\
Start and number of wet days per-season & 0.084 \\
Nadi Joumine Antra & Number of wet days and length of rainy season & 0.001 \\
& Start and end & 0.074 \\
Start and length of rainy season & 0.861 \\
Start and length of climatic cycle & 0.505 \\
Start and number of wet days per-season & 0.177 \\
Number of wet days and length of rainy season & 0.141 \\
Sidi Abdelbasset & Start and end & 0.070 \\
& Start and length of rainy season & 0.856 \\
Start and length of climatic cycle & 0.042 \\
Number of wet days and length of rainy season & 0.774 \\
Start and end & 0.024 \\
Start and length of rainy season & 0.172 \\
Start and length of climatic cycle & 0.905 \\
Start and number of wet days per-season & 0.275 \\
Number of wet days and length of rainy season & 0.127 \\
& & 0.127 \\
\hline
\end{tabular}


respectively, a rate of 3.53 days $/ 10$ years $(p=0.049)$, 1.67 days $/ 10$ years $(p=0.034)$ and 1.56 days $/ 10$ years $(p=0.034$ ), in March (growing season). Subsequently, the monthly extreme dry spell length has changed in recent years over Ichkeul lake basin for three stations. Also note that Fritissa is located in South East semi-arid region and Wadi Joumine Antra is located in south west sub-humid region of the basin. These results also indicated that for the analyzed time period, there was significant climate change in the sub-humid region of Tunisia.

The average rainfall duration of Ichkeul Lake basin is 2.19 days and the average rainfall amount is $21.01 \mathrm{~mm}$ (Sidi Salem station). Maximum seasonal rainfall number are observed at Ghèzala dam (30 events) and Wadi Joumine Antra (29 events) stations with greater and more regular annual rainfall, whereas the minimum seasonal rainfall number ( 23 events) belong to Sidi Abdelbasset station with low annual rainfall. in south semi-arid region of the basin. The trend is significant for Sidi Abdelbasset and Sidi Salem stations with a Sen's slope of $0(p=0.001$ and $<0.0001$, respectively). At Sidi Abdelbasset station, the trend of the rainfall amount per wet spell is significant, but the Sen's slope is null $(p=0.012)$.

Weeks receiving rainfall about $20 \mathrm{~mm}$ are not able to meet 0.54-0.75 times the evaporation demand in September and April, respectively. During the early stages of growth, the crop water requirement will be about 0.7 of the evaporation demand Allen et al. [26].

The variability of start of the rainy season is similar to Ghèzala dam-Wadi Joumine Antra stations and Sidi Abdelbasset-Sidi Salem stations. On average, at Fritissa, Wadi Joumine Antra and Sidi Salem the rainy season starts on 14 September and ends, respectively, on 30, 27 and 23 April giving an average season length of 228,225 and 221 days. It was observed that in Ghèzala dam the probability to have a rainfall event starting in the fifteen days of September is 0.48 with a return period of two years [25] and continues up to $39^{\text {th }}$ meteorological weeks. The wet season at Fritissa and Sidi Abdelbasset stations ends earlier than the other stations, given their location in the driest part of the transect, This confirms the results from Mupangwa et al. [27] and Edao et al. [28] who showed that as aridity increases, the season starts late and ends early.

Correlation analysis indicated that there is no significant relationship between the start and end of the rainy season. The gradient in the relationship between the start and the end of the rainy season is most pronounced at Sidi Abdelbasset station, which implies that a delayed start of the season is probably followed by an early cessation of the rainy season. This can be explained by the fact that this station is located in the southern watershed, where the climate is semi-arid. Here also, the linear relationship between the start of the rainy season and the length of the climatic cycle is significant. It suggests that a longer climate cycle translate into an early rainy season. This result provides an additional tool for characterizing climatic zones.

It was pointed out that these results depend on the threshold value of negligible precipitation [29]. These results reflect only the case of $1 \mathrm{~mm}$ per day.

Author contributions Discussed the results and contributed to the final version of the manuscript: FL; Developed and performed the design and implementation of the research, the computations, the analysis of the data and the results and the writing of the manuscript: MM.

Data availability The data are printed in paper documents stored (archived) in office of the General Directorate of Water Resources and the Division of Dam Operation of Extreme North and Ichkeul of the Ministry of Agriculture of Tunisia, (http://www.agriculture.tn/). These data are the property of this organization, and are available in situ.

\section{Declarations}

Conflict of interest The authors declare that they have no conflict of interest.

Open Access This article is licensed under a Creative Commons Attribution 4.0 International License, which permits use, sharing, adaptation, distribution and reproduction in any medium or format, as long as you give appropriate credit to the original author(s) and the source, provide a link to the Creative Commons licence, and indicate if changes were made. The images or other third party material in this article are included in the article's Creative Commons licence, unless indicated otherwise in a credit line to the material. If material is not included in the article's Creative Commons licence and your intended use is not permitted by statutory regulation or exceeds the permitted use, you will need to obtain permission directly from the copyright holder. To view a copy of this licence, visit http://creativecommons. org/licenses/by/4.0/.

\section{References}

1. Hui W, Xuebin Z, Elaine MB (2005) Stochastic modelling of daily precipitation for Canada. Atmos Ocean 43(1):23-32

2. Bogardi JJ, Duckstein L (1993) Evénements de période sèche en pays semi-aride. Rev Sci Eau 6(1):23-44

3. Dikici M (2020) Drought analysis with different indices for the Asi Basin (Turkey). Sci Rep 10:20739. https://doi.org/10.1038/ s41598-020-77827-z

4. Reiser $\mathrm{H}$, Kutiel $\mathrm{H}$ (2007) The rainfall regime and its uncertainty in Valencia and Larnaca. Adv Geosci Eur Geosci Union 12:101-106

5. Caloiero T, Coscarelli R (2020) Analysis of the characteristics of dry and wet spells in a Mediterranean region. Environ Process 7:691-701. https://doi.org/10.1007/s40710-020-00454-3

6. Raymond F, Ullmann A, Tramblay $Y$, Drobinski $P$, Camberlin $P$ (2019) Evolution of Mediterranean extreme dry spells during the wet season under climate change. Reg Environ Change 19(8):2339-2351. https://doi.org/10.1007/s10113-019-01526-3

7. Rivoire P, Tramblay Y, Neppel L, Hertig E, Vicente-Serrano SM (2019) Impact of the dry-day definition on Mediterranean 
extreme dry-spell analysis. Nat Hazards Earth Syst Sci 19:16291638. https://doi.org/10.5194/nhess-19-1629-2019

8. Machado MJ, Benito G, Barriendos M, Rodrigo FS (2011) 500 Years of rainfall variability and extreme hydrological events in southeastern Spain drylands. J Arid Environ 75(12):1244-1253. https://doi.org/10.1016/j.jaridenv.2011.02.002

9. Salvati L, Venezian-Scarascia ME, Zitti M (2009) Monitoring drought severity in agriculture through a synthetic index based on dry periods: a case study in the Mediterranean basin. Irrig Drain 58(5):596-606. https://doi.org/10.1002/ird.441

10. Ben Mhenni N, Shinoda M, Nandintsetseg B (2021) Assessment of drought frequency, severity, and duration and its impacts on vegetation greenness and agriculture production in Mediterranean dry land: a case study in Tunisia. Nat Hazards 105:27552776. https://doi.org/10.1007/s11069-020-04422-w

11. Loon AFV (2015) Hydrological drought explained. WIREs Water 2:359-392. https://doi.org/10.1002/wat2.1085

12. Kamalkishor RA, Abhijit MZ (2015) Wet and dry spell characteristics of semi-arid region, of Western Maharashtra, India. In: E-proceedings of the 36 th IAHR World Congress, the Netherlands, 28 June-3 July, 2015, The Hague, the Netherlands

13. Ray RL, Fares A, Risch E (2018) Effects of drought on crop production and cropping areas in Texas. Agric Environ Lett 3:1-5

14. Gurian-Sherman D (2012) High and dry: why genetic engineering is not solving agriculture's drought problem in a thirsty world. UCS Publica-tions, Cambridge

15. Cherif A (2003) Le problème de l'eau en Tunisie nord-orientale: besoins, ressources locales et transferts interrégionaux. In: Eau et environnement: Tunisie et milieux méditerranéens [en ligne]. ENS Éditions, Lyon, 53, 61. ISBN: 9782847884227 . https://doi. org/10.4000/books.enseditions.867

16. Ben Mammou A, Louati MH (2007) Évolution temporelle de l'envasement des retenues de barrages de Tunisie. Rev Sci l'eau 20:201-210

17. Carcaud N (2019) Le parc national de l'Ichkeul (Tunisie): une zone humide rétrolittorale aux paysages vulnérabilisés. Projets de paysage [En ligne], 20 | 2019, mis en ligne le 22 juin 2019. https://doi.org/10.4000/paysage.522

18. Mathlouthi M, Lebdi F (2008) Event in the case of a single reservoir: the Ghèzala dam in Northern Tunisia. Stochastic Environ Res Risk Assess 22:513-528
19. Fiaz H, Ghulam N, Muhammad WB (2015) Rainfall trend analysis by using the Mann Kendall test \& Sen's Slope estimates: a case study of district Chakwal rain gauge, Barani Area, Northern Punjab Provence, Pakistan. Sci Int (Lahore) 27(4):3159-3165

20. Kendall MG (1948) Rank CORRELATION METHODS. Oxford University Press, Oxford

21. Mann HB (1945) Nonparametric tests against trend. Econ J Econ Soc 3:245-259

22. Dahal N, Shrestha UB, Tuitui A, Ojha HR (2019) Temporal changes in precipitation and temperature and their implications on the streamflow of Rosi River Central Nepal. Climate 7:3

23. Nasria M, Modarres R (2009) Dry spell trend analysis of Isfahan Province, Iran. Int J Climatol 29:1430-1438

24. Sen PK (1968) Estimates of the regression coefficient based on Kendall's tau. J Am Stat Assoc 63:1379-1389

25. Mathlouthi M, Lebdi F (2009) Analyse statistique des séquences sèches dans un bassin du Nord de la Tunisie. Hydrol Sci J 54(3):442-455

26. Allen RG, Pereira LS, Raes D (2006) SMITH. Evapotranspiration del cultivo: guias para la determinación de los requerimientos de agua de los cultivos. FAO, Roma, 298. (Estudio Riego e Drenaje Paper, 56)

27. Mupangwa W, Walker S, Twomlowa S (2011) Start, end and dry spells of the growing season in semi-arid southern Zimbabwe. J Arid Environ 75:1097-1104. https://doi.org/10.1016/j.jaridenv. 2011.05.011

28. Edao AL, Kibert K, Mamo G (2018) Analysis of start, end and length of the growing season and number of rainy days in semiarid central Refit Valley of Oromia State, Ethiopia. Adv Crop Sci Technol 6:386. https://doi.org/10.4172/2329-8863.1000386

29. Marengo JA, Liebmann B, Kousky VE, Filizola NP, Wainer IC (2001) Onset and end of the rainy season in the Brazilian Amazon Basin. J Clim 14(5):833-852

Publisher's Note Springer Nature remains neutral with regard to jurisdictional claims in published maps and institutional affiliations. 